\title{
Food allergies in children - aspects of epidemiology and diet management
}

\author{
Marcelina Walczak, Teresa Grzelak, Marta Kramkowska, Krystyna Czyżewska \\ Division of Biology of Civilization-Related Diseases, Poznan University of Medical Sciences, Poland
}

\begin{abstract}
For many years there has been a steady increase in the prevalence of allergic diseases, especially in developed countries. Scientists expect that in the year 2020, atopic diseases will be present in $50 \%$ of the population worldwide. Determining the actual scale of the food allergy problem is extremely difficult due to differences in genetic and environmental factors, as well as inconsistent methodology for population and epidemiological research. Treatment of food hypersensitivity is primarily done by excluding a particular food from the diet, while introducing nutritionally equivalent alternatives. An elimination diet should be determined independently for each individual, taking into account the cause, nature, severity and symptoms of the disease. Placing food restrictions on children can interfere with their normal development. The prevailing opinion is that only a properly formulated and followed elimination diet does not endanger the health of the patient. Numerous dietary errors committed, knowingly or unknowingly, by parents can lead to malnutrition and its consequences in their children, such as rickets, anemia, and immune disorders. Therefore, in the long-term treatment of food allergies it is recommended that the caregivers fully cooperate with a doctor, nutritionist and psychotherapist. Due to the ever-increasing incidence of allergic diseases, researchers are looking for effective methods of prevention. Recent scientific reports suggest protective effects from such substances like probiotics, polyunsaturated n-3 fatty acids, vitamin D, antioxidants as well as, certain vegetables and fruits.
\end{abstract}

Keywords: food allergy, elimination diet, nutrition, childrenIntroduction.

\section{Epidemiology}

Food can cause many unwanted symptoms in humans. Abnormal reactions of the body after ingestion of food tend to have a different clinical basis. The European Academy of Allergy and Clinical Immunology (EAACI) classifies any such symptoms as food hypersensitivity within which there are two distinctions: allergic reactions (food allergies) and non-allergic reactions (non-allergic hypersensitivity). By definition, a food allergy is an inappropriate response triggered by the immune system of the body, and repeated each time after the ingestion of a food commonly regarded as "harmless" [1-3].

Over the years there has been an increase in the prevalence of allergic diseases in the world. In 19972008, the United States reported an 18\% increase in the incidence of food allergies in children up to 18 years old. During that same time, U.S., Canada and the UK observed a three-fold increase in the incidence of allergies to peanuts among young children. It is therefore very probable that, as stated in 1997 in the White Book on Allergy, atopic disorders will affect $50 \%$ of the population by the year 2020 [4, 5].

Epidemiological studies on atopic diseases are carried out mainly in developed countries, and the results are not conclusive. It is estimated that the prevalence of food allergies among children is about $4-8 \%$ however, there are also reports suggesting that the problem may affect even more than $40 \%$ of pediatric patients. The discrepancy in the data is due to genetic and environmental diversity of the populations studied, as well as inconsistent methodology in the research. This makes 
it difficult to compare the results of analysis that come from different research centers [6-8].

Looking through the genealogy of families in which allergies to foods are present indicates the importance of genetic factors. Children of healthy parents have a $5-15 \%$ chance of manifesting allergies. If one parent suffers from allergies the probability increases to $40 \%$, and if both parents are affected, the chances are as high as $60-80 \%$. The development of an allergy phenotype may also be dependent on industrial pollution, tobacco smoke, food additives and bacterial allergens. Increased exposure to these factors can increase the risk of developing atopic diseases [9, 10].

The prevalence of food hypersensitivity in society is normally determined by questionnaire surveys. This method however, is not very precise and the results are usually overestimated. Many respondents attributed an allergy to various nonspecific symptoms appearing after eating a particular food, which is not always valid. In a study of 20000 people in the UK, 20\% of respondents reported that they have food allergies. In this group, allergy tests were performed that confirmed genuine allergies in only $1.4 \%$ of patients. Furthermore, in a Polish survey conducted under the project "EuroPrevall", food hypersensitivity was listed in $42 \%$ of children between 7-9 years of age. However, in response to the questionnaire question: "Have you ever had a doctor confirmed that your child has a food allergy?" the answer was "Yes" in only $29.6 \%$ of cases $[7,8]$.

Most patients that experience discomfort after eating food refer to it as a food allergy, and is the reason why society is dominated in the belief that this type of atopy is very common. Horvarth and Dziechciarz suggested that the increase in incidence of food allergies may not actually stem from a legitimate increase in these allergies, but from a temporary overuse of the diagnosis. Therefore, any alleged food allergy should be confirmed by a double-blind, placebo-controlled food challenge (DBPCFC) [6, 11, 12].

\section{Diet management}

Food allergies can be the first manifestation of atopic disease. Due to the immaturity of the gastrointestinal tract and immune system, infants and young children get sick more often than adults. With age, the symptoms may disappear completely, can be minimized, or they can change form - referred to as "allergic march". The course of disease is mainly dependent on the type of allergen. Food allergies can be caused by any food ingested, but most often it is caused by one of "the big eight food allergens". These allergens include the protein of milk, egg, soy, peanuts and other nuts, fish, shellfish, and wheat. Studies show that approximately $85 \%$ of patients who are allergic to cow's milk, wheat and eggs may begin to tolerate them after some time; however, in allergies to peanuts, hazelnuts and seafood only $15-20 \%$ of patients develop a future tolerance to the food. A huge impact on the future health of the body is the proper treatment of an existing food allergy. The success of treatment depends on how strictly diet recommendations are followed and how knowledgeable one is about the rules of elimination diets. A properly created and followed diet plan can prevent any food deficiency related disorders like malnutrition, anemia, osteopenia, rickets, immune disorders and other irregularities [12-17].

Symptoms of food allergies significantly affect the quality of life in patients and can be fatal. The aim of nutritional therapy is controlling immune response, reducing the risk of pseudoallergic reactions, modifying the "allergic march", reducing the permeability of the mucosa barrier, restoring tolerance for food allergens, and recovering intolerance to harmful products, which indicate a healthy individual [14, 18, 19].

An expert consensus in the treatment of food allergies is only consistent in the case of a severe allergic reaction. When the disease is accompanied by milder symptoms, recommendations can be varied: using an elimination diet exclusively, adding in drug therapy, or only treating the symptoms, without any dietary restrictions. The most effective treatment for food allergies is to remove foods that cause adverse reactions from the diet altogether. There are several types of dietary guidelines for the treatment of food allergies. The first of these eliminates one or several types of foods that cause the adverse symptoms. This guideline is recommended in the case of acute allergic reactions, where specific levels of IgE are detected or there is a high probability that nutrient sources are identified to cause clinical symptoms. Most often this recommendation is used in allergies to cow's milk in infants. The second type of guideline is an oligo-antigen diet which is used when the disease symptoms appear after eating various foods. In this case, it is recommended to introduce foods into the diet that rarely cause allergies, such as lamb, rice, corn, cooked apples, broccoli, asparagus, spinach, lettuce, sweet potatoes, salt, sugar, vinegar and olive oil. If after 1-4 weeks of this diet there is no indication of better health, introduction of the third guideline is recommended, which is an elemental 
diet based on free amino acids. A common problem encountered is that pediatric patients may not accept the taste of their milk replacement. Most often this is due to the hydrolyzed whey protein or casein used in infants who are allergic to the protein in cow's milk [1, $12,18,20,21]$.

The duration of treatment using diet is individual and depends on the type of allergen, the clinical form of the disease and the patient's age, but usually should not be less than 9-12 months. Periodically, food challenge tests need to be performed in children up to 3 years of age at least every 6 months, and in older patients every 12 months. A positive test result indicates the need for continued treatment, and a lack of allergic response indicates that treatment can be stopped. The indication of an acquisition of tolerance to the original allergy-inducing food is crucial in avoiding unnecessary dietary restrictions. Reasons for the failure of nutritional therapy may include: exclusion of a food which in reality is not responsible for the symptoms of the disease, a short observation period, conscious or unconscious failure to comply with dietary recommendations, and even coexisting infections that cause symptoms similar to allergies. If the elimination of these errors does not bring the intended benefits, it is necessary to have further allergic or gastroenterological consultations, which should also include the dietician, who will help customize a menu to fit the current needs of the patient and indicate foods that may contain "hidden allergens" [18, 22]. Here is a list of products containing "hidden allergens" of cow's milk protein:

- milk in all forms

- cheese

- sour cream

- yogurt, kefir

- buttermilk

- puddings, mousses, creams

- cereals

- chocolate

- cream fudge

- sweets

- ice cream, sundaes

- some types of bread

- crepes, croquettes, pancakes

- buns, rolls and butter croissant

- cakes, pies

- some sausages

- paté

- some sauces and dressings

- mashed potatoes
- some breaded foods

- spices

- soup stock, soup cubes

- pizza, casseroles, lasagna

- canned fish

- butter

- biscuits, crackers, wafers, waffles

- some margarines [36].

The effectiveness of treatment is assessed on the basis of clinical observations, which include complete resolution or a reduction of symptoms. In children and adolescents it is particularly important to also verify whether by following an elimination diet they still have proper growth and development. It is important that the therapy recommended is not more detrimental to the patient than the symptoms [18, 22].

An elimination diet should be determined individually and adjusted to the cause and nature of the allergy, as well as the type and severity of symptoms. Before introducing dietary restrictions patients should be informed, and in the case of children their parents should be informed, about the necessity and desired outcome of treatment and the possible consequences of not following the diet. Dietary restrictions are often a source of conflict in the family because of altering the food and meals in the house, the introduction of increased discipline and the extra financial costs. The support of a doctor, nutritionist and psychologist is invaluable in this case because they indicate the therapy benefits for both the patient and their family $[22,23]$.

\section{Risks of elimination diets}

Following an elimination diet accurately is vital for infants and young children, whose bodies are in a phase of growth and development. In particular, this group of patients should not be exposed to nutritional deficiencies that may interfere with their normal physical and psychological development [22-24]. Many studies have shown that one of the main causes of child malnutrition is food allergies [25-28]. This is a consequence of inadequate food intake due to decreased appetite, excessive food losses due to persistent diarrhea and vomiting, malabsorption resulting from inflammation in the intestines, and an inappropriate choice of substitutes for the foods excluded in the diet [21, 27]. Opinions on the safety of elimination diets are divided. It is believed that only a properly composed and followed elimination diet does not endanger the health of the patient. In the process of nutritional therapy numerous dietary errors are committed, which result in imbal- 
anced feeding of children. It is particularly difficult in balancing the diet after the exclusion of a major group of products, such as milk and dairy products [24]. Adamska et al. found varying degrees of malnutrition in $26.7 \%$ of children up to 2 years of age using a dairy elimination diet, while Christine et al. showed that in a group of children treated with this elimination diet as much as $25 \%$ consume only $67 \%$ of the daily recommended amount of calcium, vitamin D, and E [29, 30]. Kurpińska et al. found that children with a cow's milk protein allergy, who received milk replacements regularly, consumed more calcium than those whose diet was not supplemented [31].

Parents' lack of knowledge concerning the proper composition of elimination diets increases the likelihood of making mistakes. It seems important, therefore, to intensify the education of caregivers of children with food allergies. Parents often unintentionally expose children to allergens. This may be due to inconsistent and inaccurate analysis of food ingredients. The evaluation of the information provided on food labels was carried out in Warsaw among 53 parents of children with celiac disease or an allergy to cow's milk protein and/or gluten. These parents had declared compliance with dietary guidelines, however it was shown that most of them had a problem with the identification of allergens on the basis of ingredients indicated on the packaging of products. A similar problem was observed by Sicherer and Sampson, giving examples of diverse and ambiguous terminology used on the labels of food products [22, 32].

\section{Conclusion}

Epidemiological data on food allergies are inconclusive. This indicates a need to standardize the methodology of a study to determine the actual extent of the problem. The only causal treatment of the disease is the use of an elimination diet. However, this may pose a risk of nutritional deficiencies, so balancing menus of pediatric patients should be monitored by a qualified nutritionist. A multitude of dietetic errors identified in children with food allergies indicates a need for greater education for their parents. Long-term use of an elimination diet should be monitored and possible nutrient deficiencies accompanied by the inclusion of vitamin and mineral supplementation.

An increase in the incidence of atopic diseases tends to lead to the implementation of effective preventive measures. Research is still looking for a relationship between the current way of life and an increased inci- dence of immune-mediated diseases. It is speculated that the most important predisposing factors for allergies are improper eating habits, environmental pollution and sterile conditions for raising children. There is evidence to suggest that certain dietary components, such as probiotics polyunsaturated n-3 fatty acids, vitamin D, antioxidant compounds, and certain vegetables and fruits, have an ability to reduce the risk of allergies, in particular in children with a family history of atopic disease [33-35].

\section{Acknowledgement}

This work was supported by a grant from the Poznan University of Medical Sciences (502-01-2228371-004458).

\section{Conflict of Interest}

The authors declare that there is no conflict of interest that could be perceived as prejudicing the impartiality of the review reported.

\section{References}

1. Kaczmarski M, Wasilewska J, Jarocka-Cyrta E, Cudowska B, Żur E, Matuszewska E, et al. Polish statement on food allergy in children and adolescents. Post Dermatol Alergol. 2011;28(5):331-367.

2. Czerwionka-Szaflarska M, Adamska I. Alergia na białka mleka krowiego u dzieci. Lekarz. 2012;4:20-26.

3. Rybak A. Wytyczne postępowania w alergii na białko mleka krowiego według World Allergy Organisation. Stand Med Pediatr. 2010;7(5/6):739-747.

4. Nowak-Węgrzyn A. Alergia pokarmowa - epidemia XXI-ego wieku? Alergia. 2011;3:9-13.

5. Kaczmarski M, Jarocka-Cyrta E. Nadwrażliwość pokarmowa i czynnościowe zaburzenia motorycznego przewodu pokarmowego. Stand Med Pediatr. 2009;6:905-906.

6. Boyce JA, Assaad A, Burks AW, Jones SM, Sampson HA, Wood RA, et al. Guidelines for the diagnosis and management of food allergy in the United States: summary of the NAID-sponsored expert panel report. Nutr Res. 2011; 31:61-75.

7. Kaczmarski M, Korotkiewicz-Kaczmarska E, Bobrus-Chociej A. Aspekty epidemiologiczne, kliniczne i społeczne alergii pokarmowej. Przegl Pediatr. 2008;38:215-217.

8. Majkowska-Wojciechowska B, Wardzyńska A, Łuczyńska M, Kowalski M, Makowska J, Kowalski M. Nadwrażliwość na pokarmy w populacji dzieci szkolnych w Łodzi - wyniki badań ankietowych w projekcie „EuroPrevall". Alerg Astma Immunol. 2009;14:35-44.

9. Pałgan K, Bartuzi Z. Czynniki genetyczne i środowiskowe w rozwoju alergii na pokarmy. Postępy Hig Med Dośw. 2012;66:385-391.

10. Adamska I, Kupczyk K, Czerwionka-Szaflarska M. Profilaktyka alergii pokarmowej - hydrolizaty, probiotyki i prebiotyki. Pediatr Współcz. 2009;11:47-52.

11. Boznański A, Łątkowska A. Alergie pokarmowe. In: Boznański A (ed.). Choroby alergiczne wieku rozwojo- 
wego. Wydawnictwo Lekarskie PZWL, Kraków 2003, 217-239.

12. Horvath A, Dziechciarz P. Alergia na pokarm - kto pyta nie błądzi. Podstawowe kroki diagnostyczno-terapeutyczne. Stand Med. 2011;8:559-566.

13. Kaczmarek J, Kuna P. Czy możemy modyfikować przebieg alergii pokarmowej immunoterapią? Terapia. 2011;19(4): 132-140.

14. Kaczmarski M, Maciorkowska E, Semeniuk J, Daniluk U, Gocoł M. Dieta eliminacyjna w alergii pokarmowej. Przegl Alergol. 2004;1:30-34.

15. Kaczmarski M. Nadwrażliwość pokarmowa u dzieci i młodzieży. Stand Med. 2009;6:379-398.

16. Zawadzka-Krajewska A. Rola diety eliminacyjnej w alergii pokarmowej. Terapia. 2008;16:30-34.

17. Wróblewska B. Wielka ósemka alergenów pokarmowych. Alergia. 2002/2003;4:18-23.

18. Zielińska I, Czerwionka-Szaflarska M. Leczenie dietetyczne w chorobach alergicznych. Pediatr Współcz. 2010; 12:126-129.

19. Zielińska-Duda H. Zespół złego wchłaniania jako manifestacja alergii pokarmowej u dzieci. Pediatr Współcz. 2009;11:55-58.

20. Czerwionka-Szaflarska M, Zawadzka-Gralec A. Alergia pokarmowa u niemowląt i dzieci - objawy, diagnostyka, leczenie. Pol Merkuriusz Lek. 2007;23:443-448.

21. Zielińska I, Czerwionka-Szaflaraska M. Niedożywienie u dzieci jako następstwo alergii pokarmowej. Klin Pediatr. 2010;2:237-240.

22. Kaczmarski M, Korotkiewicz-Kaczmarska E, Chrzanowska U. Znaczenie edukacji w procesie leczenia choroby przewlekłej ze szczególnym uwzględnieniem leczenia dietetycznego alergii pokarmowej u dzieci i młodzieży. Przegl Pediatr. 2010;40:9-15.

23. Buczek S, Kamer B, Pasowska R. et al. Ocena żywienia niemowląt i małych dzieci z alergią pokarmową. Pediatr Współcz. 2006;8:175-179.

24. Adamska I, Świątek K, Czerwionka-Szaflarska M, Zawadzka-Gralec A. Wpływ eliminacyjnej diety bezmlecznej na stan odżywienia dzieci do ukończenia drugiego roku życia. Pediatr Współcz. 2007;9:29-36.

25. Mowszet K, Piasecka A, Reich M, Iwańczak F. Przyczyny niedożywienia dzieci do lat pięciu w materiale własnym. Adv Clin Exp Med. 2005;14:315-322.

26. Gębala A, Czaja-Bulsa G, Korlatowicz-Bilar A, Woźniak-Prajwowska A, Ogrodowska M, Kacperska M. Ocena stanu odżywienia u dzieci hospitalizowanych z różnych przyczyn pediatrycznych. Pediatr Współcz 2008;10:133-136.
27. Kostrzewska M, Funkowicz M, Wąsowska-Królikowska K. Ocena przyczyn niedoboru masy ciała u małych dzieci. Pediatr Współcz. 2005;7:211-213.

28. Bała G, Czerwionka-Szflarska M, Swincow G, Rytarowska A. Analiza przyczyn niedożywienia u dzieci do lat 2. Pediatr Współcz. 2004;6:23-26.

29. Adamska I, Świątek K, Czerwionka-Szaflarska M. Spożycie wapnia u dzieci z nadwrażliwością na białka mleka krowiego leczonych dietą eliminacyjną. Pediatr Współcz. 2006;8:7-11.

30. Christie L, Hine RJ, Parker JG, Burks W. Food allergies in children affect nutrient intake and growth. J Am Diet Assoc. 2002;10:1648-1651.

31. Kurpińska P, Weker H, Rowicka G, Strucińska M. Ocena postępowania żywieniowego u dzieci z alergią pokarmową na białka mleka krowiego. Post Żyw Klin. 2010;5: 12-16.

32. Jakubik N, Topczewska-Cabanek A, Banaszkiewicz A, Szajewska $\mathrm{H}$. Interpretacja etykietek na produktach spożywczych przez rodziców dzieci na diecie bezglutenowej lub z alergią na białka mleka krowiego. Pediatr Współcz. 2004;6:173-177.

33. Prescott $S$, Nowak-Węgrzyn A. Strategies to prevent or reduce allergic disease. Ann Nutr Metab. 2011;59(Supl. 1):28-42.

34. Ribeiro CC, Leite Speridião PD, Morais MB. Knowledge and practice of physicians and nutritionists regarding the prevention of food allergy. Clin Nutr. 2012;5:1-6.

35. Leo S, Dean J, Chan ESWhat are the beliefs of pediatricians and dietitians regarding complementary food introduction to prevent allergy? Allergy Asthma Clin Immunol. 2012;21:8-15.

36. Conti L. Najczęstsze alergie pokarmowe. In: Conti L (ed.). Alergie i nietolerancje pokarmowe. Bellona, Warszawa 2007, 51-74.

Correspondence address: Marcelina Walczak Division of Biology of Civilization-Related Diseases 6 Swiecickiego Street 60-780 Poznan, Poland phone: +48618546476 fax: +48618546477 email: marcelina.walczak@poczta.onet.pl 